\title{
“THE GOSPEL ACCORDING TO AHASUERUS": APOCRYPHAL DISCOURSE OF THE NOVEL “THE WANDERING JEW” BY S. HEYM
}

\section{Ilinska N. I.}

\section{INTRODUCTION}

Multi-genre nature is one of the features of postmodern historical novel "The Wandering Jew" (1981) by S. Heym. Its multi-level structure covers the genre elements of a historical and philosophical novel, a religious historical novel, an a myth / anti-myth novel, an apocryphal novel. The apocryphal discourse of the novel, marked by the legendary image of Ahasuerus and the non-canonical image of Jesus, has a plot-forming role. These images belong to the category of eternal ones, endowed with stable semantics and associations. Their use in a literary text creates a multidimensional interpretative field, which includes the tragic experience of mankind with its existentials (profane and sacred, sin and piety, holiness and demonic, theomachism and faith, fidelity and betrayal, etc.).

The author's transformations become especially evident in comparison with pretexts. In S. Heym's novel there are several of them. We should mention the Old Testament apocryphal "The Book of Adam and Eve", the canonical Gospels, telling about the earthly way of Jesus and His sacrificial deed; medieval apocryphal legend of Ahasuerus; The Revelation of St. John the Divine; allusions from the apocryphal Gospel of Judas, the Second Book of Enoch. All of them are subjected to the author's interpretation in the genre form of the work, which synthesizes the events of the canonical and apocryphal gospels with the narrative structures and poetics of the postmodern novel. Hence the aim of the study is to consider the theoretical aspects of the concept of an "apocryphal novel"; to analyze the strategies of "apocryphization” in S. Heym's novel "The Wandering Jew" at the plot-compositional and figurative levels; to find out the author's intentions of the inversion of the canonical pretext.

\section{Theoretical aspects of the concept of an apocryphal novel. Principles of apocryphization}

As we know, apocryphal literature is considered to be one of the four sources that nourish world literature along with mythology, folklore, religion and epic. Traditionally, the apocrypha was a list of texts of unknown origin with mystical or esoteric content, intended for initiates. Apocryphal sources included originals spoiled by copyists, as well as books that were not included in the biblical canon ${ }^{1}$.

1 Літературознавча енциклопедія : У двох томах. Т. 1. / Авт.-уклад. Ю.І .Ковалів. К.: ВЦ «Академія», 2007. С. 84. 
Apocryphal literature is wide and diverse, nevertheless there are two main groups: the Old Testament apocrypha ("The Testament of the Twelve Patriarchs", "The Apocalypse of Baruch”, "The Slavic Book of Enoch”, "The Testament of Abraham", etc.) and the New Testament ("The Gospel of Judas", "The Gospel of Philip," "The Gospel of Thomas" ("The Gospel of the Childhood"), etc.). Compared to the Old Testament Apocrypha, which is multi-genre in nature, the New Testament is written in the gospel genre with rare exceptions (for example, "The History of Joseph the Carpenter”, "Jesus in the Temple”).

It should be noted that a similar trend dominates the headings of modern apocryphal novels as a special genre variety, which originates in the paradigm of classical aesthetics of the 19th century. For example, "The Gospel of Judas" by G. Panas (1973), "The Gospel According to Jesus Christ” by J. Saramago (1991), "The Gospel of Pilate” by E.-E. Schmidt (2000), "Lamb. The Gospel According to Biff, Christ's Childhood Pal” by Ch. Moore (2002) and others. I. Nabytovich approves the idea of "the birth of a modern novel (as one of the most widespread and productive genre formations of the Modernism era) from the sources of the sacred", that "its basis is the religious outlook of homo religious" ${ }^{2}$. Indeed, the non-classical aesthetics of the $20^{\text {th }}$ and $21^{\text {st }}$ centuries constantly turns to canonical and para-Christian primary sources, updating the processes of apocryphization, mythologization and demythologization, which leads to the dithering of religious canons in the literature of modernism and postmodernism. Their result is the formation of experimental genre forms, including an apocryphal novel and a myth- novel, the boundaries between which are transparent and interpenetrate ${ }^{3}$.

Apocryphal texts appear at the same time with the canonical gospels, as well as before and after their creation from the end of the 1st to the fifth century in various Christian groups. I. Sventsitskaya sees the reason for their creation in the growing interest in the earthly life of Jesus and his surroundings ${ }^{4}$. As we know, the canonical gospels are reluctantly allowed into the private life of the Savior, so folk fantasy fills these gaps. The apocrypha reflected various traditions and teachings related to the life and sermons of Jesus, their distinctive interpretation ${ }^{5}$. Apparently, these aspects of apocryphal texts are also relevant for modern literature, recreating the image of Christ and interpreting the spiritual aspects of His teachings with a certain degree of freedom in relation to Christian dogma. From this point of view, all fiction thematically related to biblical history is apocryphal (A. Men).

${ }^{2}$ Набитович I. Універсум sacrum”у в художній прозі (від Модернізму до Постмодернізму) : Монографія. - Дрогобич-Люблін : Посвіт, 2008. С. 141.

${ }^{3}$ См. об этом : Ротай С.В. Роман-апокриф как жанровая форма: методология и поэтика. Автореферат канд. филол. наук. Краснодар, 2010. С. 7, 9. 20 с.

${ }_{4}^{4}$ Апокрифы древних христиан (Перевод и исследование И.С. Свенцицкой и М.К.Трофимовой). М.: Сфера, 2004. С. 8.304 с.

${ }^{5}$ Там же. 
Studies on the theoretical and historical-literary aspects of the apocryphal novel are modestly represented in modern literary criticism. These are articles and monographs by A. Tatarinov ${ }^{6}$, O. Savelieva ${ }^{7}$, our works ${ }^{8}$. Special place is occupied with dissertations by S. Rotay, L. Serebryakova, A. Nalobin ${ }^{9}$. In these works the methodology, poetics and typology of the apocryphal novel are the subject of special study. Researchers analyze the historical and literary aspects of the genesis and development of literary works, based on the gospel story. They state the vagueness of the criteria and the terminological "polyphony" in determining the genre structure of the apocryphal novel, and identify techniques for the romanticization and of canonical characters, strategies for the transcoding of the gospel story. Literary scholars define the genre nature of literary texts written on the basis of the gospel history as "stylized (literary) apocrypha” (A. Tatarinov), literary apocrypha (A. Nalobin), passionate apocrypha (O. Savelieva), "apocryphal apocrypha” (S. Yershov), "gospel novel" (A. Krasnyashchikh). It seems that the differences existing between them are covered by the more universal concept of an "apocryphal novel" (S. Rotay). At the same time, we note that this kind of genre form is not always focused only on gospel history, as some literary scholars believe (cf. "only works that reproduce the whole life path of Christ from birth to death and resurrection are called apocryphal novels ${ }^{10}$ )". An example, when the author creates a work, referring to the canonical text of the Old Testament, can be the greatest apocryphal novel of the 20th century "Joseph and His Brothers" (19261943) by T. Mann. And this is not the only case.

Literary scholars consider the introduction of a love story, everyday realities, elements of adventurous or detective stories to be the principles of the "Romanization" of the apocrypha. Indeed, one cannot disagree with this. The most striking examples in the literature of the late 20th - early $21^{\text {st }}$ centuries are the apocryphal plot basis of D. Brown's conspiracy theological novel "The Da Vinci Code" (2003) or the postmodern pastiche modeled from apocryphal and canonical sources in Ch. Moore's novel "Lamb. The Gospel According to Biff, Christ's Childhood Pal” (2002). However, the strategies for apocryphization of the image of Christ may be different, as we see in S. Heym's novel

6 Татаринов А.В. Власть апокрифа: библейский сюжет и кризисное богословие художественного текста. Краснодар, 2008 / https://textarchive.ru/c-2343814.html

${ }^{7}$ Савельева О.А. Русский апокрифический Христос: к постановке проблемы. Slavia Orientalis, 2003, № 2. C.159-178

${ }^{8}$ Ильинская Н.И.Религиозно-философские искания в русской поэтической традиции рубежей XX века : специфика сознания, концептосфера, типология : Монография. Херсон : Айлант, 2005. 468 с. С. 335-344.

${ }^{9}$ Налобин А.Литературный апокриф в русской прозе XIX - начала XX века. Автореф. дис. филол. наук. - 2014. http://os.x-pdf.ru/20filologiya/776269-1-literaturniy-apokrif-russkoyproze-xix-nachala-veka.php.

${ }^{10}$ Серебрякова Л. В. Роман-апокриф как литературный феномен : автореф. дисс. ... канд. филол. наук. Пермь, 2012 / https://studfiles.net/preview/8119168/. 
“The Wandering Jew”. The author's goal is not so much penetration to Christ's earthly life that makes his image "human", and sometimes "too human", as much as understanding the Savior's Personality and His soteriological mission on a metaphysical planetary scale.

The problem of the genre nature of S. Heym's novel attracts the attention of researchers in the context of various aspects of its study. Thus, G. Ishimbaeva in her article "Transformation of the biblical myth in postmodernism literature ("The Wandering Jew" by Stefan Heym)" defines S. Heym's work as an apocryphal novel representing the non-canonical version of the gospel story of Jesus' life and notes the non-traditional ending in it ${ }^{11}$. Agreeing with the separate positions of the work, we consider the "value center" of the work to be the path of the God-seeking of Ahasuerus, his search for Truth. The structure-forming role of this image is indicative. In a multi-level organization of the work, the mythologem of Ahasuerus combines three storylines - mythological (biblical time), historical (Germany of the $16^{\text {th }}$ century after the Reformation) and modern (socialist German Democratic Republic of the $80-\mathrm{s}$ of the $20^{\text {th }}$ century). Each of them has its own mythology. A productive definition of the genre of S. Heym's work as an apocryphal novel in the article by G. Ishimbaeva is only stated.

Some aspects of the problem we have stated, namely apocryphization of the image of Ahasuerus, are presented in the dissertation of N. Polishchuk ${ }^{12}$. She considers the "polyapocryphal nature of the mythologem of Ahasuerus", "the game aspect of the creation of meta-apocrypha," but the meaning of these interesting concepts is not specified. The urgent task of our study is to fill out the highlighted gaps by describing the apocryphal components of the multigenre structure of novel "The Wandering Jew” by S. Heym.

In our study, we define the apocryphal novel as a prosaic work focused on canonical and apocryphal sources. In contrast to the "sacred parody" (parodia sacra) - the medieval form of "playing with the sacred word"13, in the structure of which there is no doubt about the sacredness of the Holy Writ, the apocryphal novel has a subjective interpretation of the Christian dogmatics, recoding of stable meanings and emblematic images. The writer creates an author's myth, which implies a "game with shrines," a travesty of biblical stories and images, liturgical rituals, and a fun sermon. According to J. Haizinga, the game "removes the distinction between faith and pretense. This understanding of the game without any stretch of communication is related to

11 Ишимбаева Г.Г. Трансформация библейского мифа в литературе постмодернизма («Агасфер» Стефана Гейма) // www.lib.csu.ru/vch/2/1997_01/019.pdf).

12 Поліщук Н. Трансформація міфологеми Агасвера в західноєвропейській літературі XIX - XX ст. Автореф. дис... канд. філол. наук. Л., 2001. - 20 с.

13 Литературная энциклопедия терминов и понятий / Под ред. А.Н. Николюкина. Институт научн. информации по общественным наукам РАН. - М.:НПК «Интелвак», 2003. 1600 стб. С. 958. 
the concept of sanctification and the sacred", it is applicable "to the sacred consciousness, to the faith" ${ }^{14}$.

In the individual author's myth, the "mechanisms" of mythologization and demythologization are syncretically included. According to V. Toporov, they "work" "a single whole": "mythologization as the creation of the most semantically rich, energetic and powerful examples of reality images and demythologization as the destruction of stereotypes of mythopoietic thinking that have lost their "lifting power" 15 . The apocryphal novel is not located "inside the church walls" and does not solve religious and didactic problems. As N. Frye rightly observes, "even ... irreligious writers ... sometimes resort to religious terminology and symbolism," 16 since secular art plays with everything. His main motivation is creative one.

\section{Apocryphal component \\ of the novel "The Wandering Jew" by S. Heym}

The apocryphal component of the novel "The Wandering Jew" includes two storylines focused on various sources. One of them is associated with the image of Ahasuerus, who acts as an apocryphal evangelist telling the story of Rabbi Joshua; the second is based on the adogmatic version of the sin offering of Jesus Christ. In the literary text of S. Heym's apocryphal novel they are closely intertwined. We will consider the semantics and poetics of the apocryphal component of the novel in the context of author's ideology.

\subsection{The image of the apocryphal evangelist Ahasuerus}

The pretext of the first storyline is the apocryphal medieval legend of the Eternal Jew - a man who offended God. There are several of its options, reflecting changes in the national topics with a common plot. The legend tells how, on the way to Calvary, Jesus, tired of the weight of the cross, wants to stop near Ahasuerus' house for rest. However, the Jerusalem cobbler orders him to go further. As a punishment, Ahasuerus, called the Eternal Jew, is doomed to wander from century to century, waiting for the Second Coming of Christ, since only He alone can remove the curse from him ${ }^{17}$. In Germany, the myth of the Eternal Jew is widespread at the beginning of the $17^{\text {th }}$ century. It was then that there appeared a "Brief narration of a certain Jew from Jerusalem named Ahasuerus who was present at the crucifixion of Christ, and also shouted with

\footnotetext{
${ }^{14}$ Хейзинга Й.Нomo ludens. Человек играющий / Пер. с нидерл. В.В.Ошиса. М.: Изд-во ЭКСМО-Пресс, 2001. 352 с. С. 50, 52.

${ }^{15}$ Топоров В.Н. Миф. Ритуал. Символ. Образ: Исследования в области мифопоэтического: Избранное. М.: Издательская группа «Прогресс» - «Культура», 1995.- С. 5. 624 с.

${ }^{16}$ Фрай Н. Критика, религия, литература. Вопросы литературы. 1991. № 9-10. C. 157-187. C. 173.

${ }^{17}$ Аверинцев С. Агасфер. Мифы народов мира. Энциклопедия: в 2 х т. / Гл. ред. С.А. Токарев. М.: Рос. энциклопедия, 1997. С. 34.
} 
others: "Crucify him" - and cried out for Barabbas" (Kurtze Beschreibung und Erzehslung von einem Juden mit Namen Ahasvérus. Welcher bey der Creutzigung Christi selbst Persônlich gewesen auch dos Crucifige uber Christum hat helfen schreyen und umb Barrabam bitten hob auch nach der Creutzigung Christi nimmer gen Jerusalem kônnen komrnen auch sein Weib und Kinder nimmer gesehen: und seit hero im Leben geblieben) ${ }^{18}$.

Starting from the $18^{\text {th }}$ century and ending with the literature of the late $20^{\text {th }}-$ early $21^{\text {st }}$ centuries, this short story about the Wandering Jew is subjected to various interpretations, which is explained by its archetypal nature. We know C. Jung's words that if he didn't call himself Ahasuerus, "he would still have arisen under a different name" ${ }^{19}$. Enlightenment, preromantic, romantic, modernist, postmodern interpretations of the image of the Eternal Jew are developed depending on the creative personality and author's intentions. Among other stable motives of the "Ahasuerus complex" (A. Nyamtsu) - "eternal wanderings", victory over time, suffering and atonement, motives of wandering, aimlessness and infinity of existence - the invariant motive of immortality should be emphasized, as it turns into punishment in reward for righteousness (in Christianity - "Eternal life"). S. Averintsev calls this structural principle of the legend a "double paradox," when the dark and the light change places twice: immortality, the desired goal of human efforts, in this case turns into a curse, and a curse turns into mercy (the possibility of expiation) ${ }^{20}$.

This is the first layer of apocryphization in S. Heym's novel, since it transforms the invariant features of the image of Ahasuerus and the semantics of the motive of immortality, which have developed in the folklore and literary tradition. Unlike Ahasuerus from folklore sources (Jerusalem shoemaker, praetorian watchman, etc.), S. Heym's hero is endowed with a transcendental nature. He is an angel, a spirit from the Spirit of God, created on the second day of creation from flames and puff of eternity. Therefore, he is immortal by definition, therefore, a journey through the ages is a natural existence for him. Together with another angel - Lucifer (in S. Heym's novel - Leuchtentrager) he was cast down by God from heaven for refusing to worship a person from the sixth day of creation, created from mud and water (allusion to the Old Testament apocryphal "The Book of Adam and Eve”) ${ }^{21}$. The God-fighting motive, rooted in a romantic interpretation of the image of Ahasuerus, finds its

\footnotetext{
${ }^{18}$ Наумова Е.Е. Легенда об Агасфере и особенности интерпретации образа в немецкоязычной литературе XVIII-XIX веков // Филологические науки в МГИМО. 2017. № 4. / https://socionet.ru/publication.xml?h=spz:neicon:filnauki:y:2017:i:2:p:109-119\&l .

${ }_{19}$ Юнг К.Г. Бессознательное рождение героя. От Эдипа до Осириса. М., 1998. С. 286. C. 238-308.

${ }^{20}$ Аверинцев С. Агасфер. Мифы народов мира. Энциклопедия: в 2 х т. / Гл. ред. С.А. Токарев. М.: Рос. энциклопедия, 1997. С. 34.

${ }^{21}$ Житие Адама и Евы [Латинская версия] / http://apokrif.fullweb.ru/apocryph2/ adam_eva_lat.shtml.
} 
original embodiment in S. Heym's apocryphal novel, that is polyphonic in nature. The cross-cutting image of the Eternal Jew combines the myth of creation and the eschatological myth, which emphasizes its special significance in the events of the Holy History presented in the novel. The high status of the overthrown angel Ahasuerus - created by his nature - is supported by his proximity to Jesus, who is mentioned in the Revelation: "I am Alpha and Omega, the Beginning and the End” (Rev. 1: 8) ${ }^{22}$. In other words, S. Heym creates the author's mythopoetic versions focused on the myth of the creation of the Book of Genesis and the eschatology of the Apocalypse. Such a free interpretation by the author of the Holy Scripture, its addition by new characters and "coloring" with events that are absent in the canonical texts, allows us to confirm his apocryphization in the novel by "The Wandering Jew" by S. Heym.

In the history of mankind, as it reflected in S. Heym's novel, the Eternal Jew is a witness to the Golgotha's sufferings of the Savior, the Reformation and religious wars in Germany, and a participant in the revolt in the Warsaw ghetto. He is the owner of a shoe store in modern Jerusalem, the only one who has the grace to see the Second Coming of the Savior on earth, which happened at the end of the $20^{\text {th }}$ century by the will of the author of the novel.

It seems interesting to trace the similarities and differences between legendary Ahasuerus and the image of the apocryphal evangelist from S. Heym's novel. They are brought together by a feeling of dissatisfaction with Jesus' refusal from revolutionism, which they understand differently. In the first case, the historical context is taken into account - Rabbi Joshua refused to become the messiah and lead the struggle of the Jewish people against Roman sway. That is why, as it is written in the title of the national book, the shoemaker Ahasuerus shouted with the crowd "Crucify him" - and cried out for Barabbas. In the second case, we are talking about the doctrinal grounds of religion and faith.

In S. Heym's novel, Ahasuerus is a "multi-faced hero": he is a fallen angel and an apocryphal evangelist, an English sir and a preacher from Holland, a Jew who gave the dying hope of immortality and a soldier sentenced to death for desertion. But the main thing is that he is an ideologist, a spirit of doubt and an opponent of God on a planetary scale. The author's position is corresponded to him, the basis of which is doubt in man as the crown of God's creation, characteristic of Gnostic apocrypha. The author's ideology is clearly represented in the dialogue of the fallen represented in the dialogue of the fallen angel with God, artistically realized in the immanent apocrypha genre of vision (chapter 13). As befits a visionary, Ahasuerus first hears the voice of God, as the righteous Job hears it from the storm, then he sees His throne adorned with

\footnotetext{
${ }^{22}$ Исследователи констатируют двойничество образов Агасфера и реббе Йошуа. См. об этом: Борисеева Е. А. Мифологема Агасфера в литературе эпохи постмодерна / http://elib.bsu. by/handle/123456789/36674. Однако эта позиция подается без аргументации.
} 
precious stones, and finally the Almighty, filled with heavenly beauty and magnificence. God is trying to find out why Ahasuerus, who refused to be blissful in heaven and praise His glory, continues to turn everything inside out and doubt the wisdom of His creation.

In fact, the fallen angel admires the natural world of the Creator, subtly feeling its beauty and perfection. And he doubts the Divine world order and Its law: God's justice, the God-like nature of a man as His creation, the spiritual essence of Christ's sin offering. Hence Ahasuerus' provocative attempt to find out from the Almighty: "What is true - the God-like nature of a man or the humanity of God"? (compare with the canonical statement: man is God-like, but not God-equal). Without answering the question whether a person really resembles God or, on the contrary, God resembles a person, the Creator turns into a mist, leaving an empty throne in all its splendor. The symbolism is quite transparent - the attempts to reach out to God, whom Ahasuerus wanted to love with all his heart, are vain, in return only fog and emptiness remain. Father which is in Heaven is not the God of love. He is the Universe to which feelings are unknown. The actualization of the adogmatic thought about the God-leaving of mankind, about the indifference of the Creator to His creation is one of the methods of apocryphization of biblical truths, motifs and images in S. Heym's novel "The Wandering Jew".

In the dialogue between God and the fallen angel Ahasuerus, explicit and implicit allusions to biblical and apocryphal texts, transcoded by the author in an ironic mode, are "scattered". Such, for example, is the allusion to the ladder of Jacob (Genesis 38: 10-22), which Isaac's son sees in a dream. It connects heaven and earth so that angels ascend and descend on it, which personifies the unity of God and the human world. The translated apocrypha "Jacob's Ladder" is based on this biblical story, the symbolism of which portends the coming of Christ to earth.

In S. Heym's novel, Ahasuerus, like Jacob, observes the movements of little white, with pink-headed angels, heavily lowering the empty throne to the earth, which will be occupied by the Lord. The narrator ironically notes that from the side it seems that the angels are just dragging furniture. The obvious subtext of this statement serves as demythologization both the sacred ritual of the Epiphany and the character. The same desacralizing connotations contain an allusion from the apocryphal "Jacob's Ladder" to the future appearance of Christ: according to the Evangelist Ahasuerus, a miserable figure of Rabbi Joshua looked through the splendor of the Old Testament God.

The allusions to the Book of Job are more "hidden". This Book is one of the most difficult to interpret books of the Old Testament. So, the figure of the long-suffering Job, asking God uncomfortable questions, is superimposed by an ironic projection on the image of Ahasuerus, who is also punished by the Higher powers and also thinks about God's injustice. Like Job, he argues with God, blames Him, revealing impudence and stubbornness. Both characters are 
united by the desire to know the essence of the God-like nature of a man. In a polemic with the Almighty, the Eternal Wanderer ironizes over his "double curses": first, God the Father, and then His Son, as if the one was not enough. And then the narrator's sarcastic attack against the Holy Trinity follows: it remains to join the Holy Spirit, that is little known about.

Among the allusive images from the Book of Job, transformed in S. Heym's novel "The Wandering Jew", one should name the sea monster - the leviathan. God is especially proud of his creation and power over him and considers it one of the most weighty proofs of His greatness and power. However, in the text of S. Heym's apocryphal novel, God's creationism is inverted to a molecule, which only He could create. It is perceived as a parody detail against the background of God's achievements of the Book of Job. So, on the path of knowledge of God as a result of a conversation with the Almighty, Ahasuerus comes to a disappointing conclusion: both God and the world He created are far from perfection, full of contradictions and need to be corrected. Ahasuerus tries to make Rabbi Joshua his ally on the path of changing the unfair world order of God the Father, so that He, if he is actually the Son of God, will destroy the old world and build the kingdom of heaven on earth.

\subsection{The apocryphization of the version of "The Gospel according to Ahasuerus"}

The adogmatism and Ahasuerus' atheistic boldness of the thinking is clearly manifested in the version of earthly life of Rabbi Joshua and the assessment of His sin offering. The compositionally apocryphal "The Gospel according to Ahasuerus" is a "text in a text" and consists of five chapters (chapters 5, 8, 12, 20, 29). It is based on the author's modification of several genre structures and motifs, namely: stories of Jesus' temptation by the devil in the wilderness (chapter 5), the passionate canon of the synoptic Gospels (chapters 8, 12), the Revelation of John the Theologian in the eschatological end of the novel (chapter 29), the motifs of the apocryphal Gospel of Judas, the folklore motifs of Judas' seducing by the devil. The named pretexts were rethought by S. Heym in the spirit of a "high game" with religious and cultural values, in a modus of irony and sarcasm, which are aimed at the images of the Old Testament God, the Son of Man and the idea of His sin offering.

In S. Heym's novel, there remains a roll call with apocryphal sources in the thoughts of the essence of Christ ${ }^{23}$ : who is He, the God-man, as the dogma of the Orthodox Church says, or He need to prove that He is really the Son of God? If he is the Son of God, can he even have a human nature, and if he is the son of a carpenter, can he be part of the Divine Trinity? Is the crucified Rabbi Joshua the omnipotent messiah, who the prophet says about will judge the nations and

${ }^{23}$ См. об этом : Апокрифы древних христиан (Перевод и исследование И.С. Свенцицкой и М.К. Трофимовой). М.: Сфера, 2004. С. 8. 
make them reforge swords on sickles? Or could He be the savior of people like everyone created in the image and likeness of God, because he believed in it? These questions are asked by the apocryphal evangelist Ahasuerus, who, unlike the legendary character (we will use the words of Goethe), is "ennobled by love for Christ”, as evidenced by his statements and actions.

The Eternal wanderer, who knows the fate of Rabbi Joshua, driven by love and compassion, is trying to save Him from his cross tortures in an earthly way. In his opinion, He should become the messiah for the people of Israel and lead a rebellion against the Romans, but He chooses the path drawn by God. In the dialogue between Ahasuerus and Rabbi Joshua (chap. 5), everyone defends an individual understanding of the essence of God, the world order and their mission.

If Ahasuerus' God is the Creator of those kingdoms of the world where the strong humiliate and oppress the weak, then Joshua unquestioningly believes in His Divine love and forgiveness. If Ahasuerus understands that the kingdom of God's justice can be created only with a sword in his hands, then Rabbi Joshua believes that this is the destiny of the meek and humble, because the Kingdom of God is not of this world. Therefore, Ahasuerus sees the coming Messiah strong, endowed with power and avenging enemies, and Rabbi Joshua righteous, saving and meek. His messiah, who will take upon himself the sin of the world, will ride the holy city of Yerushalayim not as a victor on a white horse, but he will sit on a young donkey. The dialogue includes an extensive reminiscence-allusion layer, which marks the speech of the interlocutors. Turning to the biblical intertext, the author creates a witty situation where, using scripture quotes, polemicists confirm opposing points of view. Apparently, by this method S. Heym wanted to emphasize that the "crisis of authorities" came much earlier than the theorists of postmodernism announced this.

As we know, the gospel Jesus Christ is represented by two forms: Christ in Glory - the supreme judge of the last times, and Kenotic Jesus - the humble Lamb that "will not break the broken cane and will not extinguish the smoked flax” [Is. 42:3; Matt. 12:20]. In the apocryphal discourse of S. Heym's novel "The Wandering Jew", on the foreground there is weakness, humbleness, and humility to Rabbi Joshua - a meek lamb doomed to slaughter, which manifests itself both in appearance and in character. Knowing that He will be betrayed, hated, ridiculed and mocked by those who, three days ago, laid their clothes under the hooves of His donkey, He humbly goes towards fate in order to drain the cup that the Father prepared for Him. It is significant that over time, Ahasuerus overestimates Joshua's humility. Instead of blind obedience to God, Ahasuerus sees the greatness and strength of the spirit of Rabbi in His ability to resist the temptations and go His way to the end. So in the gospel history the thoughts of a twentieth century man on freedom of existential choice are interwoven. This idea is developed by S. Heym in the motive of Judah's betrayal.

In the canonical Gospels, the love of money (Matt. 25: 14-16; Mk. 14: 10-11) and obsession with demon (Luke 22: 3-6; Jn. 13:27) are considered to be the 
motives of Judas' betrayal. However, these versions are questioned in other sources - the apocryphal Gospel of Judas ${ }^{24}$, in the historical and cultural studies of this problem ${ }^{25}$, in the works of modernism and postmodernism: the novelessay "Unknown Jesus" by D. Merezhkovsky (1932-1933), stories by L. Andreev "Judas Iscariot” (1907), J.L. Borges "Three versions of Judas" (1944), apocryphal novels by A. Burgess "Man of Nazareth” (1979), N. Mailer "The Gospel According to the Son" (1991), and J. Saramago "The Gospel According to Jesus Christ" (1997); E.-E. Schmidt "The Gospel of Pilate" (2000). This list can be continued. Their authors review the traditional notion of one of the twelve apostles as "a thief and a traitor". In these works, Judas becomes a faithful ally of the Savior from the snitcher and the profit-seeker. He is entrusted with a tragic role in the realization of the Divine mission of Christ. He goes through his Dolorosa: he commits a sin by "betraying the virgin Blood" (Matt. 27: 4), deprives himself of the life bestowed by God, remains in the memory of mankind as a symbol of betrayal of all times and nations. Is all this because of love and infinite devotion to Jesus or there are other mysterious reasons? D. Merezhkovsky wonders: in the case of Judas, does "one have to solve the equation with two unknowns, to solve one dark riddle and the other that is darker? The only conclusion to this is that the stones at Judah need to be cast more carefully - Jesus is too close to him" ${ }^{26}$.

How does S. Heym riddle this "riddle"? In his novel, Judas is deprived of the tragic halo of the martyr devoted to Christ. According to the apocryphal evangelist Ahasuerus, this apostle is the most unpleasant one of the twelve Jesus' disciples. He is cunning and dodgy. Contrary to traditional ideas, Lucifer does not seek or seduce him. He doesn't need a demon. The miserable man of Judas, ready to betray his Master for 30 pieces of silver. It is only one of the arguments in the long-standing dispute of an overthrown angel with God, a testimony to the meanness of His creation. When the Almighty did not succeed in destroying a man by flood, brimstone, or war, he decided to send a redeemer - His Son, who would take on others' sins and suffer for the human race. "There is nothing to say, a good thought, but the Author is not better”, Lucifer says sarcastically.

In S. Heym's novel the image of Judas reflects the worldview of a man of the $20^{\text {th }}$ century who has lost stable axiological orientations. As an experienced manipulator, Lucifer gives the apostle a truly devilish advice: to place responsibility for treachery on the Master and on God, since everything is already predestined. At the Last Supper, so it happened: the Lord stretched out

${ }^{24}$ Евангелие от Иуды / https://www.liveinternet.ru/users/mila111111/post14605798/.

25 Эрман Б. Утерянное Евангелие от Иуды.Новый взгляд на предателя и преданного http://rubooks.net/author.php?author; Михайлов С. Иуда Искариот: предатель или святой? : Исследование / Malkin.

${ }^{26}$ Мережковский Д. Иисус Неизвестный. М.: Эксмо, 2007. С. 505.752 с. - (Антология мысли). 
to the "son of perdition" a piece of bread, dipping it into a sauce of bitter herbs, and said, "What do you do, do it sooner" (Jn 13:27).

In the dialogue between Judas and Ahasuerus one of the main problems of the novel is solved - the problem of predestination and free will. The disciple of Christ does not consider himself a traitor, for he only fulfilled the last will of Rabbi, though in fact the words of Lucifer were fulfilled. Ahasuerus objects to Judas: in spite of predestination, God always reserves the right to choose between good and evil, and the last word is after a man. Therefore, Judas became a traitor by his own will, breaking the moral commandments of being. Thus, through the Gospel story of S.Heym, the author consolidates its connection with the ontological issues of modernity, following the path of anthropologization. In the apocryphal discourse of his novel, the higher powers that rule over a man appear not so much transcendental or infernal factors as the man himself with his responsibility for thoughts and deeds.

One of the most pressing problems of the Christian Church - the meaning and consequences of the sacrificial sacrifice of Jesus Christ - is emphasized in S. Heym's novel "The Wandering Jew". In the canonical version it is said that Christ died for all men, taking on their sins (“... Christ died for our sins ... He was buried ... and rose again on the third day, according to Scripture ..." (I Corinthians 15: 3-6)). This doctrinal position has been subjected to a thorough revision by the author on several aspects, that also testifies to the apocryphization of the gospel history. Thus, in S. Heym's apocryphal novel in the inseparable Divine-human nature of Jesus his human hypostasis is emphasized. Only in the final paintings of Armageddon Ahasuerus for the first time states Rabbi Joshua's God-parity of God the Father. The leitmotif in the text of the work is Ahasuerus' thought, according to which Jesus fulfilled His Father's will without thinking about what would change after His sacrifice. Ahasuerus' words that God the Father made people as they are, and Jesus wants to change them with his pitiful death (ch. 12), are the culmination of a dispute between a fallen angel and the Son of God. It was the doubts about the righteousness of the act of the Father who sacrificed the Son for the redemption of human sins, as well as Ahasuerus' confidence in the futility of this sacrifice, served his punishment.

Artistically, this thought is embodied in a number of Ahasuerus' invectives against humanity that forgot the Sermon on the Mount and continued to commit lawless acts; in the actualization of the folklore motif of the "unrecognized Christ" - His Second Advent to the Holy City of Jerusalem remained unnoticed for all but Ahasuerus. The author uses a direct quotation from the Christian denomination formula as an ironic testimony that for most people Jesus exists only as a Symbol of Faith with which the Son of God who ascends to heaven identifies Himself. He is lifeless, as if cut out of wood and painted, and the halo is the embodiment of His holiness, barely shimmers. Christ himself, like His Father, became indifferent to men. He confesses that by redeeming their 
guilt with his sacrifice, he did not exterminate the sin itself. The apocalyptic paintings of Armageddon in the finale of the novel, stylized by the Revelation of John the Theologian, are expressions of the author's thought, according to which the last questions are not solved even in this battle, and God remains a great thought and dream.

\section{CONCLUSIONS}

In S. Heym's novel, “The Wandering Jew” the apocryphal discourse is the ideological and stylistic dominant of the multy-genre structure of the work. It is based on two vectors: 1) modification of the legendary image of Ahasuerus and 2) adogmatic interpretation of the Christ's sin offering. The name Ahasuerus in the title and the role in the plot-compositional organization of the text allow to stay that he is the main character of the novel. Endowed with angelic nature and immortality, Ahasuerus acts as a mediator between the sacred and profane realms. The ambivalence and ambiguity of the image of Ahasuerus gives him features of oxymoronicity: on the one hand, he bears a curse as doomed to exile from heaven; on the other, he shows grace as a witness of gospel events and a harbinger of the Second Advent of Christ. In Ahasuerus' world, such a feature of postmodern consciousness as epistemological uncertainty is manifested. It is caused by the so-called "crisis of authority". His path is the search for Truth.

Using apocryphal plots and motives, the textual structures of the passive canon (the entrance of the Lord to Jerusalem, the Last Supper, the cross of Christ, the destruction of the veil in the temple), direct evangelical and theological quotations, S. Heym creates narration with a different semantic content. Apocryphization is manifested in the non-traditional functions of the characters, in the liturgical intentions, in the recoding of the semantics of images in a parody-ironic mode.

The peculiarity of the apocryphal novel "The Wandering Jew" by S. Heym is the rejection of the traditional principles of romanization at the expense of love story, psychologization of sacred characters or penetration into the reality of their private life. Its adogmatic dominance of the interpretation of Sacred History and sacred images suggests that S. Heym creates an apocryphal novel of a new type - ideological, polyphonic in structure.

\section{SUMMARY}

The article deals with the theoretical aspect of the concept of "apocryphal novel”, its difference from other literary transformations of Old Testament and canonical subjects and images. The specificity of the apocryphal discourse, its plot and meaning-forming functions in S. Heym's novel "The Wandering Jew" are revealed. It is indicated that its components are a modification of the legendary image of Ahasuerus, an apocryphal evangelist in the text of the novel, and a semantically related narrative of the earthly ministry and the sin offering 
of Jesus. The principles of apocryphization and transcoding of the canonical gospels, as well as other religious and paralegal sources, are analyzed. The conclusions about the anti-dogmatic intentions of the author of the apocryphal novel "The Wandering Jew" are made, which aim at any manifestations of monopoly on truth and utopianism.

\section{REFERENCES}

1. Аверинцев С. Агасфер. Мифы народов мира. Энциклопедия: в 2-х т. / Гл. ред. С.А. Токарев. М.: Рос. энциклопедия, 1997. С. 34.

2. Апокрифы древних христиан (Перевод и исследование И.С. Свенцицкой и М.К. Трофимовой). М.: Сфера, 2004. 304 с.

3. Борисеева Е. А. Мифологема Агасфера в литературе эпохи постмодерна / http://elib.bsu. by/handle/123456789/36674.

4. Евангелие от Иуды / https://www.liveinternet.ru/users/mila111111/ post14605798/.

5. Житие Адама и Евы [Латинская версия] / http://apokrif.fullweb.ru/ apocryph2/adam_eva_lat.shtml.

6. Ильинская Н.И.Религиозно-философские искания в русской поэтической традиции рубежей XX века : специфика сознания, концептосфера, типология : Монография. Херсон : Айлант, 2005. С. 335-344.

7. Ишимбаева Г.Г. Трансформация библейского мифа в литературе постмодернизма («Агасфер» Стефана Гейма) // www.lib.csu.ru/vch/2/1997_ 01/019.pdf.

8. Литературная энциклопедия терминов и понятий / Под ред. А.Н. Николюкина. Институт научн. информации по общественным наукам РАН. - М.:НПК «Интелвак», 2003. - 1600 стб.

9. Літературознавча енциклопедія : У двох томах. Т1 / Авт.-уклад. Ю.І. Ковалів. К.: ВЦ «Академія», 2007. С. 84.

10. Мережковский Д. Иисус Неизвестный. М.: Эксмо, 2007. 752 с. (Антология мысли).

11. Михайлов С. Иуда Искариот: предатель или святой? : Исследование / Malkin.

12. Набитович I. Універсум sacrum у в художній прозі (від Модернізму до Постмодернізму) : Монографія. - Дрогобич-Люблін : Посвіт, 2008. 600 с.

13. Налобин А. Литературный апокриф в русской прозе XIX - начала XX века. Автореф. дис. филол. наук. - 2014. http://os.X-pdf.ru/20filologiya/ 776269-1-literaturniy-apokrif-russkoy-proze-xix-nachala-veka.php.

14. Наумова Е.Е. Легенда об Агасфере и особенности интерпретации образа в немецкоязычной литературе XVIII-XIX веков // Филологические науки в МГИМО. 2017. № 4. / https://socionet.ru/publication.xml? h=spz:neicon:filnauki:y:2017:i:2:p:109-119\&l. 
15. Поліщук Н. Трансформація міфологеми Агасвера в західноєвропейській літературі XIX - XX ст. Автореф. дис. ... канд. філол. наук. Л., 2001.20 с.

16. Ротай С.В. Роман-апокриф как жанровая форма: методология и поэтика. Автореферат канд. филол. наук. Краснодар, 2010. 20 с.

17. Савельева О.А. Русский апокрифический Христос: к постановке проблемы. Slavia Orientalis, 2003, № 2. C. 159-178.

18. Серебрякова Л.В. Роман-апокриф как литературный феномен : автореф. дисс... канд. филол. наук. Пермь, 2012 / https:/studfiles.net/ preview/8119168/.

19. Татаринов А.В. Власть апокрифа: библейский сюжет и кризисное богословие художественного текста. Краснодар, 2008 / https://textarchive.ru/ c-2343814.html.

20. Топоров В.Н. Миф. Ритуал. Символ. Образ: Исследования в области мифопоэтического: Избранное. М.: Издательская группа «Прогресс» «Культура», 1995. 624 с.

21. Фрай Н. Критика, религия, литература. Вопросы литературы. 1991. № 9-10. С. 157-187.

22. Хейзинга Й.Ноmo ludens. Человек играющий / Пер. с нидерл. В.В. Ошиса. М. : Изд-во ЭКСМО-Пресс, 2001. 352 с.

23. Эрман Б. Утерянное Евангелие от Иуды. Новый взгляд на предателя и преданного. URL: http://rubooks.net/author.php?author.

24. Юнг К.Г. Бессознательное рождение героя. От Эдипа до Осириса. M., 1998. C. 238-308.

\section{Information about the author: Ilinska N. I.}

Doctor of Philology, Professor, Head of the Department of World Literature and Culture named after professor O. Mishukov of the Kherson State University 40 rokiv Zhovtnya str., Kherson, 73000, Ukraine 